IOS Press

\title{
Effects of cultivars and coco-substrates on soilless strawberry production in Cyprus
}

\author{
Damianos Neocleous* \\ Agricultural Research Institute, Ministry of Agriculture, Natural Resources and Environment, Nicosia, Cyprus
}

Received 12 March 2012; accepted 24 March 2012

\begin{abstract}
This experiment was conducted to generate up-to-date, practical and location specific information for soilless strawberry production in Cyprus. Commercial 'fresh' strawberry plants (Fragaria $\times$ ananassa Duch) of three cultivars ('Camarosa', 'Festival', and 'Ventana') were cultivated from October 2010 to June 2011, using coco-substrates from three different brands (BVB, Wonder Soil, Pelemix) in a 2 levels-pyramid layout. Harvesting started in January and lasted until June. The total yield obtained was similar in all cultivars and of about $439 \mathrm{~g}$ plant $^{-1}$. However, with 'Ventana' and 'Festival' 'extra' category fruits and berry mass were advanced. Early yield (Jan-April) was higher in 'Festival' compared with 'Camarosa' and 'Ventana' was in between. Amount of water consumed to produce one $\mathrm{kg}$ of fruit fresh weight (WUE), was lower in 'Ventana' and 'Festival' compared to 'Camarosa'. No differences were observed in productive characteristics, early yield and WUE according to the substrate. Regarding quality, fruits of 'Festival' and 'Ventana' retained higher soluble solids to acid ratio, where as fruits of 'Camarosa' performed higher levels of bioactive compounds. The results from this study suggest 'Festival' and 'Ventana' as interesting alternative cultivars.
\end{abstract}

Keywords: Fragaria x ananassa, coconut fibre, yield, water use, quality

\section{Introduction}

During the last years, the interest in soilless culture in Mediterranean countries is increasing due to exhausted soils, soil disinfection, and water quality and availability $[18,20]$. Strawberries are the most important berry crop cultivated in Europe and one of the most important crops cultivated in soilless systems [21]. Moreover, strawberry production and growth areas increase each year not only because of its highly consumable fruits, but also for the nutritional value of the fruit-rich in antioxidants [21, 26].

It is estimated that soilless culture in Cyprus represents 45.7 ha (10\% of the total greenhouse cultivation area). This is relatively low and likely due to growers having knowledge of greenhouse production and the use of substrates [19]. The cultivated strawberry is the most important berry crop in Cyprus accounting for 32 ha and 1840 ton production [7]. Moreover, it is one of the most important crops cultivated under soilless conditions, with 'Camarosa' consisting the prevailing cultivar the last decade, using fresh plants that are autumn planted. Soilless culture aims to achieve an efficient growing system for strawberries using as substrate slabs of coconut fibre or rockwool. Coconut fibre is widely used the last years because is easy to use, produce good yield, is a renewable source that can be incorporated to the soil and re-use is possible [17]. However, the need of the growers for improving production, earliness and quality of the fruits is essential to enhance fresh consumption.

*Corresponding author: Damianos Neocleous, Agricultural Research Institute, Ministry of Agriculture, Natural Resources and Environment, Nicosia, Cyprus. Tel.: +357 22 403115; Fax: +357 22 316770; E-mail: d.neocleous@ arinet.ari.gov.cy. 
The aim of this experiment was to generate up-to-date, practical and location specific information for soilless strawberry production in Cyprus. Particularly the effects of three cultivars ('Camarosa', 'Festival', 'Ventana') and coconut fibre substrates from three different brands (BVB, Pelemix, Wonder Soil) on plant productivity, earliness, water use efficiency and fruit quality was evaluated.

\section{Materials and methods}

\subsection{Plant material and growth conditions}

Commercial 'fresh' strawberry plants (Fragaria $\times$ ananassa Duch) of three cultivars ('Camarosa', 'Festival', 'Ventana') were cultivated in a $567 \mathrm{~m}^{2}$ plastic greenhouse (ARI, Cyprus, $34^{\circ} 94^{\prime} \mathrm{N}, 33^{\circ} 19^{\prime} \mathrm{E}$ ) using coco-substrates from three different brands (BVB, Wonder Soil and Pelemix) wrapped in polyethylene slabs $(100 \mathrm{~cm} \times 15 \mathrm{~cm} \times 7 \mathrm{~cm})$ and placed on Polygal troughsin a 2 levels-pyramid layout $\left(20.6\right.$ plants $\mathrm{m}^{-2}$ ). The average temperature and humidity during the experimental period from October, 2010 to June, 2011 , were $22^{\circ} \mathrm{C}$ and $75 \%$. The mean global solar radiation was $17.5 \mathrm{MJ} \mathrm{m}^{-2}$.

\subsection{Handling and harvesting}

Plants were supplied with a known amount of nutrient solution, the drainage (30\% run-off) was measured and the difference was the water consumption by the plants. The irrigation schedule was to keep the electrical conductivity in the root environment relatively constant. Water use efficiency (WUE) was defined as the amount of water consumed to produce one $\mathrm{kg}$ of fruit fresh weight. A nutrient solution consisting of the following concentrations of macronutrients (mmol/l): $5.2 \mathrm{~K}, 3.5 \mathrm{Ca}, 1.5 \mathrm{Mg}, 12 \mathrm{~N}-\mathrm{NO}_{3}, 0.6 \mathrm{~N}_{-} \mathrm{NH}_{4}, 1.25 \mathrm{P}_{-} \mathrm{H}_{2} \mathrm{PO}_{4}, 1.1 \mathrm{~S}_{-} \mathrm{SO}_{4}$, and trace elements $(\mu \mathrm{mol} / \mathrm{l})$ : $10 \mathrm{Mn}, 20 \mathrm{Fe}, 4 \mathrm{Zn}, 0.75 \mathrm{Cu}, 0.5 \mathrm{Mo}$ and $20 \mathrm{~B}$, was applied to deliver essential nutrients.

Harvesting (twice a week) started in January and lasted until June. Harvested fruits were weighted and separated into 'extra' and 'B' categories. Fruits of 'B' category were characterised by malformation, various defects, or weight less than $15 \mathrm{~g}$. Fruits for quality analysis were harvested at the optimum of fruit maturity at three harvesting periods (January, March and May) and results are the mean values, unless noted otherwise. The fruits of each replicate were weighted and flesh firmness was determined. Then calyxes were removed, fruits were frozen, placed in polyethylene bags and stored at $-30^{\circ} \mathrm{C}$.

\subsection{Photosynthetic parameters}

The following measurements were performed on the youngest fully expanded leaf, 2-h after the sunrise in six plants per replication atbimonthly intervals and results are the mean values i) net assimilation rate (A), stomatal conductance $\left(\mathrm{g}_{\mathrm{s}}\right)$, intercellular $\mathrm{CO}_{2}$ concentration $(\mathrm{Ci})$ and transpiration $(\mathrm{E})$ were measured using Li-6400 (Li-Cor, Lincoln, NE-USA) according to the equations derived by von Caemmerer and Farquhar [27].

\subsection{Analyses}

Soluble Solids concentration (SS) was determined in the homogenized sample using a refractometer (Atago PR-1, Tokyo, Japan). The titratable acidity (TA) was measured by mixing $10 \mathrm{~g}$ of the pulp and $124 \mathrm{ml}$ distilled water and titrating with $0.1 \mathrm{~N} \mathrm{NaOH}$ ( $\mathrm{pH} 8.1$ ), and expressed as \% citric acid. The ratio of SS/TA was calculated. For the determination of dry matter (DM), $10 \mathrm{~g}$ of berry pulp were dried at $60^{\circ} \mathrm{C}$ for $48 \mathrm{~h}$.

Ascorbic acid content was determined by using Reflectoquant ascorbic acid test strips in an RQflex reflectometer (Merck, Darmstadt, Germany). Results were expressed as mg ascorbic acid (AA) per $100 \mathrm{~g}$ FW. Anthocyanin content was determined according to Cordenunsi et al. [5]. Anthocyanin content was estimated as mg pelargonidin-3-glucoside equivalents per $100 \mathrm{~g} \mathrm{FW}$ using a molar absortivity coefficient of 36,000. For total phenolics, flavonoids and ferric reducing antioxidant power (FRAP assay) samples $(5 \mathrm{~g})$ were extracted with a mixture containing acetone, water and acetic acid $(70: 29.5: 0.5, \mathrm{v}: \mathrm{v}: \mathrm{v})$ [10]. The content of total phenolics was measured according to Scalbert et al. [24] 
Table 1

Total yield, 'extra' fruits, berry mass and water use efficiency (WUE)

as affected by strawberry cultivar and substrate

\begin{tabular}{lcccc}
\hline Treatment & $\begin{array}{c}\text { 'Extra'fruits } \\
(\mathrm{g} / \mathrm{plant})\end{array}$ & $\begin{array}{c}\text { Total yield } \\
(\mathrm{g} / \mathrm{plant})\end{array}$ & $\begin{array}{c}\text { Berry mass } \\
(\mathrm{g} / \mathrm{fruit})\end{array}$ & $\begin{array}{c}\text { WUE** } \\
(\mathrm{l} / \mathrm{kg})\end{array}$ \\
\hline Cultivar & & & & \\
Camarosa & $224 \mathrm{~b}$ & 422 & $11.0 \mathrm{c}$ & $48.5 \mathrm{a}$ \\
Festival & $306 \mathrm{a}$ & 447 & $13.6 \mathrm{~b}$ & $43.9 \mathrm{ab}$ \\
Ventana & $323 \mathrm{a}$ & 449 & $14.7 \mathrm{a}$ & $41.4 \mathrm{~b}$ \\
Substrate & & & & \\
BVB & 290 & 450 & 12.9 & 41.4 \\
Pelemix & 289 & 440 & 13.4 & 45.7 \\
WS & 275 & 428 & 13.0 & 46.6 \\
C $\times$ S & $\mathrm{ns} *$ & $\mathrm{~ns}$ & $\mathrm{~ns}$ & $\mathrm{~ns}$ \\
\hline
\end{tabular}

Means within a column followed by different letters are significantly different according to Duncan's multiple range test at $P<0.05$ level, *nonsignificant,

**amount of water consumed to produce one $\mathrm{kg}$ of fruit fresh weight.

using the Folin-Ciocalteu's phenol reagent. Gallic acid was used as standard and the results expressed as milligrams of gallic acid equivalent (GAE) per g FW. For total flavonoids assay a protocol previously described by Kim et al. [14] was employed. Total flavonoid content was calculated from a calibration curve using catechin as the standard, and expressed as mg catechin equivalents per g FW. FRAP was determined using the method of Benzie and Strain [2]. Ascorbic acid (AA) was used as standard and the results were expressed as $\mu$ mol AA per g FW.

\subsection{Experimental design and statistical analysis}

Experiment was arranged in a randomized block design with factorial arrangement of treatments and four replications. Each plot consisted of one 2 levels-pyramid with a density of 20.6 plants $\mathrm{m}^{-2}$. Data were analyzed using the means procedure of SAS/ASSIST.

\section{Results and discussion}

The total yield obtained from 'Ventana', 'Festival' and 'Camarosa' was similar (Table 1) and corresponded to 9.3, 9.2 and $8.8 \mathrm{~kg} \mathrm{~m}^{-2}$ respectively. However, 'Ventana' and 'Festival'produced higher amount of 'extra' category fruits (Table 1) and increased berry mass compared to 'Camarosa' (Table 1). Total fruit yield, 'extra fruits' and berry mass were not affected by substrates and across cultivars averaged $439 \mathrm{~g} \mathrm{plant}^{-1}, 284 \mathrm{~g} \mathrm{plant}^{-1}$ and $13.1 \mathrm{~g}$ fruit ${ }^{-1}$, respectively. Fruit yield obtained in the current experiment when expressed per unit surface area, was within the range of earlier reports [17]. Cultivar and substrate selection for protected strawberry cultivation should be location specific and may depend on the desired period for peak production [1,22]. In our study, harvesting started in January and lasted until June (Fig. 1). The peak of the production lasted approximately 30 days between 15 March and 15 April (Fig. 1) and this period coincides with high values in local market. Early yield (Jan-April), as a percentage of the total production, was higher in 'Festival' (82.9\%) compared with 'Camarosa' $(73.3 \%)$ and 'Ventana' was in between $(77.5 \%)$ (Fig. 2). These results coincide with the notion that adapted strawberry cultivars must offer growers greater early fruit production when strawberries are not readily available in the market and carry a high price. No differences were observed on early yield results according to the substrates (data not shown).

Water consumption of 'Ventana', 'Festival' and 'Camarosa' strawberry plants corresponded to 366, 385 and $405 \mathrm{~lm}^{-2}$, respectively (data not shown). Accordingly, WUE was lower in 'Ventana' followed by 'Festival' and 'Camarosa' (Table 1). Substrates did not affect WUE (Table 1), although plant water consumption showed a decline with BVB substrate $\left(369 \mathrm{~lm}^{-2}\right)$ compared with Pelemix and Wonder Soil, that gave similar values (avg. $\left.395 \mathrm{~lm}^{-2}\right)$ 


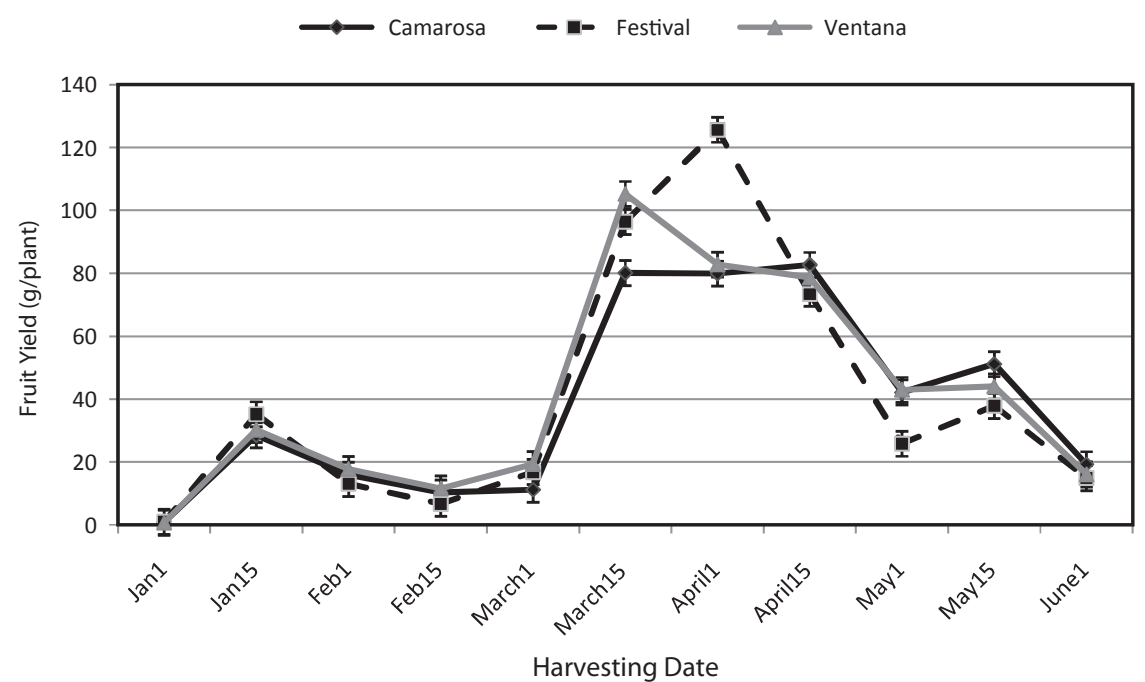

Fig. 1. Variation in production of three strawberry cultivars ('Camarosa', 'Festival', 'Ventana') during the experimental period. The bars represent the standard error of the mean $(n=4)$.

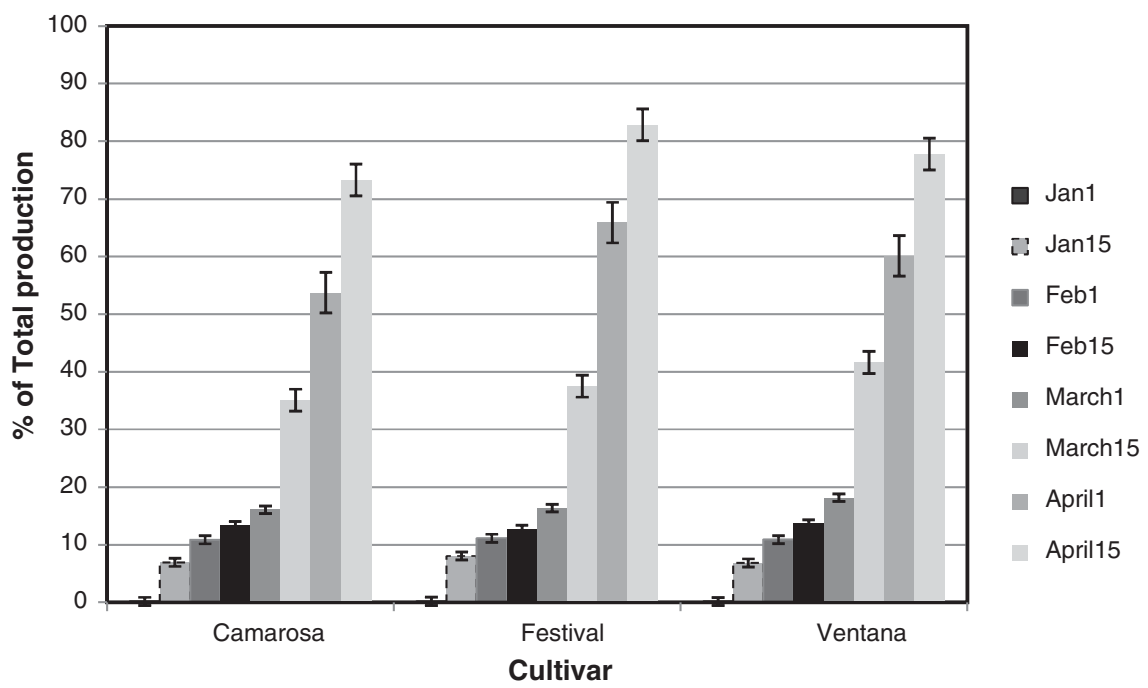

Fig. 2. Early yield (January-April) of three strawberry cultivars ('Camarosa', 'Festival', 'Ventana') as a percentage of the total fruit yield. The bars represent the standard error of the mean $(n=4)$.

(data not shown). Today growers are under increasing pressure to increase water efficiency in several horticultural crops [3]; particularly in Mediterranean climatic conditions WUE is one of the most desirable traits of any cultivar. However, strawberry plants are very sensitive to drought stress and for long-term sustainability there is a need to select water efficient genotypes [9]. Moreover, it is economically relevant to know the specific amount of water consumed to produce one $\mathrm{kg}$ of fruit fresh weight, since the cost of water is balanced by the sale price of the product [25]. On the available data, 'Ventana' showed better efficiency in water management, followed by 'Festival' and 'Camarosa'.

Statistical analysis determined that there were no effects due to cultivar or substrate on photosynthetic parameters. Net assimilation rate (A) averaged $16.1 \mu \mathrm{mol} \mathrm{CO}_{2} \mathrm{~m}^{-2} \mathrm{~s}^{-1}$; stomatal conductance $\left(\mathrm{g}_{\mathrm{s}}\right)$, averaged $0.332 \mathrm{~mol} \mathrm{H}_{2} \mathrm{O} \mathrm{m}^{-2}$ $\mathrm{s}^{-1}$; intercellular $\mathrm{CO}_{2}$ concentration $(\mathrm{Ci})$ averaged $279 \mu \mathrm{mol} \mathrm{CO}_{2} \mathrm{~mol}^{-1}$ and transpiration (E) averaged $3.39 \mathrm{mmol}$ 
Table 2

The effect of strawberry cultivar and substrate on dry matter (DM), pH, soluble solids (SS, ${ }^{\circ}$ Brix), titratable acidity (TA, \%citric acid), ascorbic acid [mg AA $\left(100 \mathrm{~g} \mathrm{FW}^{-1}\right.$ ], total anthocyanins [mg pelargonidin-3-glucoside $(100 \mathrm{~g} \mathrm{FW})^{-1}$ ], total flavonoids [mg catechin $(\mathrm{g} \mathrm{FW})^{-1}$ ],total phenolics [mg Gallic Acid $\left(\mathrm{g} \mathrm{FW}^{-1}\right]$ and antioxidant capacity-FRAP values $\left[\mu\right.$ mol AA $(\mathrm{g} \mathrm{FW})^{-1}$ ] of strawberry fruits

\begin{tabular}{|c|c|c|c|c|c|c|c|c|c|c|}
\hline Treatment & $\mathrm{DM}$ & $\mathrm{pH}$ & SS & TA & SS/TA & Asc. acid & Total anth. & Total flavon. & Total phen. & FRAP values \\
\hline \multicolumn{11}{|l|}{ Cultivar } \\
\hline Camarosa & 7.4 & 3.6 & $6.9 \mathrm{a}$ & $0.92 \mathrm{a}$ & $7.7 \mathrm{~b}$ & $35 \mathrm{a}$ & $30 a$ & $0.69 \mathrm{a}$ & $2.5 \mathrm{a}$ & $20 \mathrm{a}$ \\
\hline Festival & 7.3 & 3.7 & $6.8 \mathrm{a}$ & $0.72 b$ & $9.5 \mathrm{a}$ & $36 \mathrm{a}$ & $23 b$ & $0.47 \mathrm{c}$ & $2.2 \mathrm{~b}$ & $16 b$ \\
\hline Ventana & 7.1 & 3.7 & $6.3 b$ & $0.69 \mathrm{~b}$ & $9.2 \mathrm{a}$ & $31 b$ & $24 b$ & $0.56 \mathrm{~b}$ & $2.1 b$ & $16 b$ \\
\hline \multicolumn{11}{|l|}{ Substrate } \\
\hline BVB & 7.1 & 3.7 & 6.7 & 0.77 & 8.9 & 35 & 26 & 0.56 & 2.2 & 17 \\
\hline Pelemix & 7.3 & 3.6 & 6.7 & 0.78 & 8.9 & 33 & 26 & 0.59 & 2.3 & 18 \\
\hline WS & 7.2 & 3.6 & 6.7 & 0.78 & 8.7 & 34 & 25 & 0.56 & 2.2 & 17 \\
\hline $\mathrm{C} \times \mathrm{S}$ & $\mathrm{ns}^{*}$ & ns & ns & ns & ns & ns & ns & ns & ns & ns \\
\hline
\end{tabular}

Means within a column followed by different letters are significantly different according to Duncan's multiple range test at $P<0.05$ level, *nonsignificant.

Table 3

The overall effect of the harvesting period on dry matter (DM), $\mathrm{pH}$, soluble solids ( $\left.\mathrm{SS},{ }^{\circ} \mathrm{Brix}\right)$, titratable acidity (TA, \%citric acid), ascorbic acid [mg AA $\left(100 \mathrm{~g} \mathrm{FW}^{-1}\right.$ ], total anthocyanins [mg pelargonidin-3-glucoside $\left(100 \mathrm{~g} \mathrm{FW}^{-1}\right.$ ], total flavonoids [mg catechin $\left(\mathrm{g} \mathrm{FW}^{-1}\right]$, total phenolics [mg Gallic Acid $\left(\mathrm{g} \mathrm{FW}^{-1}\right]$ and antioxidant capacity-FRAP values $\left[\mu\right.$ mol AA $\left.(\mathrm{g} \mathrm{FW})^{-1}\right]$ of strawberry fruits

\begin{tabular}{lcccccccccc}
\hline Harvest. period & DM & $\mathrm{pH}$ & SS & TA & SS/TA & Asc. acid & Total anth. & Total flavon. & Total phen. & FRAP values \\
\hline January & $7.4 \mathrm{a}$ & 3.7 & $7.4 \mathrm{a}$ & $0.71 \mathrm{~b}$ & $10.5 \mathrm{a}$ & $34 \mathrm{a}$ & $21 \mathrm{c}$ & $0.47 \mathrm{~b}$ & $1.7 \mathrm{c}$ & $14 \mathrm{c}$ \\
March & $6.6 \mathrm{~b}$ & 3.6 & $6.1 \mathrm{c}$ & $0.74 \mathrm{~b}$ & $8.3 \mathrm{~b}$ & $32 \mathrm{~b}$ & $25 \mathrm{~b}$ & $0.51 \mathrm{~b}$ & $2.1 \mathrm{~b}$ & $17 \mathrm{~b}$ \\
May & $7.5 \mathrm{a}$ & 3.6 & $6.5 \mathrm{~b}$ & $0.87 \mathrm{a}$ & $7.7 \mathrm{~b}$ & $35 \mathrm{a}$ & $31 \mathrm{a}$ & $0.74 \mathrm{a}$ & $2.9 \mathrm{a}$ & $22 \mathrm{c}$ \\
\hline
\end{tabular}

$\mathrm{H}_{2} \mathrm{O} \mathrm{m}^{-2} \mathrm{~s}^{-1}$. Net assimilation rate corresponded well to earlier reports [4] and it was consistent with the respective yield results.

Regarding fruit quality, 'Festival' and 'Ventana' were interesting for higher SS/TA ratio compared to 'Camarosa'. This may suggest better taste since taste quality usually depends on the ratio of soluble solids to titratable acidity. However, all cultivars showed SS/TA ratio adequate to achieve best quality [5, 23] (Table 2). The phenolic compounds usually found in strawberry are phenolic acids, flavonoids and anthocyanins [15]. Dissimilar to SS/TA ratio, 'Camarosa' fruits performed higher values of anthocyanins, flavanoids and phenolics which resulted to a higher antioxidant capacity as measured by FRAP assay (Table 2). Moreover, higher anthocyanin content may indicate a more attractive color given that anthocyanins account for the color in strawberry fruits [8]. These values corresponded to earlier reports $[12,23]$ and any minor discrepancies may be attributed to various factors such as cultivar effect, climatic conditions and experimental set up. No differences in fruit quality were observed according to the type of coco-substrate (Table 2). These results revealed that differences in the antioxidant capacity exist in strawberry fruit, which depend on genotype [13], and may provide both growers and consumers with health benefit information.

Correlations coefficients for different antioxidant compounds and antioxidant capacity were calculated. A significant linear correlation (Pearson) was observed between antioxidant capacity (FRAP) and anthocyanins, flavanoids and total phenolics $\left(r=0.71^{* * *}, r=0.89^{* * *}, r=0.86^{* * *}\right.$, respectively). In line with our results, a considerable body of data suggests that that a higher content of total phenolics, flavonoids and anthocyanins in strawberry enhances their antioxidant activity $[11,15,28]$. Inversely, ascorbic acid was not correlated with antioxidant capacity. Törrönen and Määtä [26] mentioned only a small contribution of ascorbic acid to total antioxidant capacity compared to total phenolics and flavonoids. To summarize, quality was mainly related to genotype and not to the type of coco-substrate. This confirms the importance of having soilless-adapted varieties for greenhouse production with improved and stable fruit quality [6]. 
Finally the impact of the harvesting period on fruit quality parameters was studied. Harvesting from January to May improved studied bioactive compounds and antioxidant activity of fruits, but taste quality related SS/TA ratio was negatively affected (Table 3). These variations were probably influenced by temperature, irradiance and leaf: fruit ratio, which may affect the formation and accumulation of carbon-based metabolites, thus, the quality parameters of strawberry fruits $[6,16]$. Seasonal variation in antioxidants compounds observed may influence consumers' preference in case of a diet rich in antioxidants.

\section{Conclusions}

'Festival' and 'Ventana' appear to be interesting alternative cultivars. These cultivars attained early fruit production with large fruits of good taste quality and good efficiency in water management. However, 'Camarosa' produced fruits with higher antioxidant compounds and a more attractive color. The type of coco-substrate was not a limiting factor. The use of an optimum time for planting, the cultivars and plant support media used along the management of the nutrient solution, would allow lengthening of the fruiting season and particularly greater yields in December and January of high quality fruits and has to be investigated.

\section{References}

[1] Anagnostou K, Vasilakakis MD. Effects of substrate and cultivar on earliness, plant productivity, and fruit quality of strawberry. Acta Hort. 1995; 379: 267-74.

[2] Benzie FFI, Strain JJ. The ferric reducing ability of plasma (FRAP) as a measure of "Antioxidant Power". The FRAP assay. Anal Biochem. 1996; 239: 70-6.

[3] Bordonaba JG, Terry LA. Differential effect of water deficit irrigation on fruit quality of five june-bearing strawberry cultivars. Acta Hort. 2009; 838: 187-91.

[4] Carlen C, Potel AM, Ançay A. Photosynthetic response of strawberry leaves to changing temperatures. Acta Hort. 2009; 838: 73-76.

[5] Cordenunsi BR, Nascimento JRO, Lajolo FM. Physico-chemical changes related to quality of five strawberry fruit cultivars during coolstorage. Food Chem. 2003; 83: 167-73.

[6] Diamanti J, Capocasa F, Mezzetti B, Tulipani S, Battino M. The interaction of plant genotype and temperature conditions at ripening stage affects strawberry nutritional quality. Acta Hort. 2009; 838: 183-6.

[7] Food and Agriculture Organization [homepage on the Internet]. Statistics Division; 2012 [updated 2012 February 23; cited 2012 March 12]. Available from: http://faostat.fap.org/.

[8] Hernanz D, Recamales ÁF, Meléndez-Martínez AJ, González-Miret ML, Heredia FJ. Assessment of the differences in the phenolic composition of five strawberry cultivars (Fragaria $\times$ ananassa Duch.) grown in two different soilless systems. J Agric Food Chem. 2007; 55: 1846-52.

[9] Johnson AW, Grant OM, Davies MJ, James CM, Passey AJ, Simpson DW. Investigating the response of strawberry to water deficit conditions. Acta Hort. 2009; 838: 169-73.

[10] Kähkönen M, Hopia A, Heinonen M. Berry phenolics and their antioxidant activity. J Agric Food Chem. 2001; 49: 4076-82.

[11] Kalt W, Forney CF, Martin A, Prior RL. Antioxidant capacity, vitamin C, phenolics, and anthocyanins after fresh storage of small fruits. J Agric Food Chem. 1999; 47: 4638-44.

[12] Kamperidou I, Vasilakakis M. Effect of propagation material on some quality attributes of strawberry fruit (Fragaria $x$ ananassa, var. Selva). Sci Hort. 2006; 107: 137-42.

[13] Keutgen A, Pawelzik E. Modifications of strawberry fruit antioxidant pools and fruit quality under NaCl stress. J Agric Food Chem. 2007; 55: 4066-72.

[14] Kim DO, Chun OK, Kim YJ, Moon HY, Lee CY. Quantification of polyphenolics and their antioxidant capacity in fresh plums. J Agric Food Chem. 2003; 51: 6509-15.

[15] Kosar M, Kafkas E, Paydas S, Baser KHC. Phenolic composition of strawberry genotypes at different maturation stages. J Agric Food Chem. 2004; 52: 1586-9.

[16] Krüger E, Potel AM, Ancay A. Photosynthetic response of strawberry leaves to changing temperatures. Acta Hort. 2009; 838: 73-6.

[17] López-Medina J. The use of substrates for strawberry production in Spain. In: Proc. Alternatives to methyl bromide-The remaining challenge. Sevilla, Spain; 2002: p. 77-81.

[18] Magnani G, Grassotti A, Nessi B. Lapillus growing medium for cut bulbous flowers in soilless culture. Acta Hort. 2003; 609: 389-93.

[19] Neocleous D, Polycarpou P. Gravel for soilless tomato culture in the Mediterranean region. Int J Veg Sci. 2010; 16: 148-59. 
[20] Neocleous D, Vasilakakis M. Effects of NaCl stress on red raspberry (Rubus idaeus L. 'Autumn Bliss'). Sci Hort. 2007; 112: 282-9.

[21] Palencia P, Martinez F, Ribeiro E, Pestana M, Gama F, Saavedra T. Relationship between tipburn and leaf mineral composition in strawberry. Sci Hort. 2010; 242: 242-6.

[22] Paranjpe AV, Cantliffe DJ, Lamb EM, Stoffella PJ, Powell C. Winter strawberry production in greenhouses using soilless substrates: An alternative to methyl bromide soil fumigation. Proc Fla State Hort Soc. 2003; 116: 98-105.

[23] Roussos PA, Denaxa N-K, Damvakaris T. Strawberry fruit quality attributes after application of plant growth stimulating compounds. Sci Hort. 2009; 119: 138-46.

[24] Scalbert A, Monties B, Janin G. Tannins in wood: Comparison of different estimation methods. J Agric Food Chem. 1989; 37 : 1324-29.

[25] Schröder F-G, Liet JH. Irrigation control in hydroponics. In: Savvas D, Passam H, editors. Hydroponic production of vegetables and ornamentals. Athens: Publications Embryo; 2002: 263-98.

[26] Torre CL, Barrit BH. Quantitative evaluation of Rubus fruit anthocyanin pigments. J Food Sci. 1977; 42: 488-90.

[27] Von Caemmerer S, Farquhar GD. Some relationships between the biochemistry of photosynthesis and the gas exchange of leaves. Planta. 1981; 153: 376-87.

[28] Wang SY, Lin HS. Antioxidant activity in fruits and leaves of blackberry, raspberry and strawberry varies with cultivar and developmental stage. J Agric Food Chem. 2000; 48: 140-6. 